\title{
Canadian Contributions to Anabaptist Studies since the 1960s
}

\author{
JONATHAN R. SEILING \\ University of Hamburg
}

\begin{abstract}
Anabaptist studies in Canada have been marked by an exceptional degree of productive, interconfessional (or non-confessional) engagement, most notably between Mennonites, Baptists, and Lutherans. The institutions making the greatest contributions have been at the University of Waterloo (including, but not exclusively, Conrad Grebel University College), Queen's University, and Acadia Divinity College. The geographic expansion of Anabaptist studies beyond the traditional Germanic centres into eastern Europe and Italy, and the re-orientation of analysis away from primarily theological or intellectual history toward a greater focus on socio-political factors and networking, have been particular areas in which Canadian scholars have impacted Anabaptist studies. The relationship of Spiritualism (and later Pietism) to Anabaptist traditions and the nature of Biblicism within Anabaptism, including the greater attention to biblical hermeneutics with the "Marpeck renaissance," have also been studied extensively by Canadians. International debates concerning "normative" Anabaptism and its genetic origins have also been driven by the past generations of Canadian scholars (monogenesis, polygenesis, post-polygenesis).
\end{abstract}

Les études anabaptistes ont été marquées au Canada par un degré exceptionnel de collaboration productive, interconfessionnelle et non-confessionnelle, en particulier entre les mennonites, les baptistes, et les luthériens. Les institutions qui ont le plus contribué à cette collaboration sont les établissements de Waterloo (y compris, entre autres, le Conrad Grebel University College), la Queen's University et l'Acadia Divinity College. Les études anabaptistes ont déployé leurs intérêts au-delà des centres germaniques traditionnels vers l'Europe de l'Est et l'Italie. Les chercheurs canadiens en études anabaptistes ont contribué de façon importante aux transformations de leur discipline, qui ont amené cette dernière à séloigner de l'histoire théologique et intellectuelle fondamentale pour se concentrer davantage sur les facteurs et les réseaux socio-politiques $d u$ mouvement anabaptiste. Les chercheurs canadiens ont aussi approfondi les thèmes de la relation du spiritisme (et plus tard, du piétisme) avec les traditions anabaptistes, et du biblicisme propre à l'anabaptisme, incluant l'intérêt croissant pour l'herméneutique biblique dans le cadre de la Renaissance de Marpeck. Des générations de chercheurs canadiens ont également fait leur marque dans les débats internationaux au sujet de l'anabaptiste "normatif » et de sa généalogie (monogenèse, polygenèse, post-polygenèse).

1. I wish to express thanks to Hans-Jürgen Goertz, the anonymous reviewers, and the editors for their many helpful suggestions, which have improved the scope and accuracy of this study.

Renaissance and Reformation / Renaissance et Réforme 37.4, Fall / automne 2014 
$\mathrm{O}$ ver the past decades, the studies of Anabaptism and the so-called "radical Reformation" have truly come of age, and Canadian scholars ${ }^{2}$ have played a major role in several key developments. The Brill collection, A Companion to Anabaptism and Spiritualism, ${ }^{3}$ was a landmark accomplishment of the entire field of Reformation radicalism. The volume was edited by James M. Stayer, professor emeritus of Queen's University, and John Roth, the current editor of the Mennonite Quarterly Review (MQR). Five of its thirteen articles were written by Canadians: Geoffrey Dipple, ${ }^{4}$ Michael Driedger, ${ }^{5}$ John Rempel, ${ }^{6}$ Arnold Snyder, ${ }^{7}$ and James Stayer. ${ }^{8}$ As a whole, the Companion clearly demonstrates the potential for a renewed and continued collaboration between academic researchers who do not primarily aim to serve confessional agendas and scholars of different disciplines who have varying degrees of affinity with the convictions of the religious groups they study.

Since the 1960s, Canadian scholars-including Mennonites, Baptists, and Lutherans, as well as those who claim no religious affiliation-have made a proportionately high contribution to the study of Anabaptism. Studies by Canadians of Spiritualism and Pietism-topics congruent with the study of Anabaptism-also continue to play leading roles internationally in the broad field of Reformation radicalism. The role of a scholar's religious confession, or lack thereof, no longer determines the value or nature of one's contributions to the field as it once did.

The ideological scrutiny of ecclesiastical history has been a particular preoccupation within Anabaptist studies. Since the mid-1900s many scholars of the radical Reformation, particularly in Canada, have taken seriously various

2. Unless otherwise mentioned, the scholars listed below are Canadian or have spent the majority of their career in Canadian institutions.

3. James M. Stayer and John D. Roth, eds., A Companion to Anabaptism and Spiritualism, 1521-1700 (Leiden: Brill, 2007). For a more detailed outline of the contents, see my review of the Companion in the Toronto Journal of Theology 24.1 (2008): 133-35.

4. Chapter 7, “The Spiritualist Anabaptists," 257-97.

5. Chapter 13, "Anabaptists and the Early Modern State: A Long-Term View," 507-44.

6. Chapter 10, "Anabaptist Religious Literature and Hymnody" 389-424.

7. Chapter 2, "Swiss Anabaptism: The Beginnings, 1523-1525," 45-81.

8. "Introduction," xiii-xxiv; chapter 3, “Swiss-South German Anabaptism, 1526-1540," 83-117. 
social-scientific, even explicitly Marxist ${ }^{9}$ or "profane" approaches to the study of religious phenomena; moving away from a theologically-determinate focus toward an analysis of the social dimension of Anabaptism was particularly vital to the evolution of this sub-field of Reformation studies. The connections of Anabaptism with the peasants' revolts of the mid-1520s have been debated since the inception of the movement itself, but due in part to scholars such as Stayer a more nuanced account of the tumultuous rise of the "re-baptising" movement has become widely accepted. Narrowly theological or "intellectual history" approaches could not adequately determine the coherence of Anabaptism, which was not merely a set of theological ideas in the same way as other confessional traditions could point to denominationally-unifying theologians or doctrines, but it was a social movement, whose very message was tied to its rejection of social and even intellectual hierarchies. Also, from the start of Anabaptism its disunity was more apparent than its unity, and this inevitably drove scholars to inquire repeatedly into its genesis. The inter-connections of the earliest groups of re-baptisers remain a mystery to some degree to the present. While the study of Anabaptist history may still mask hidden ideological or theological polemics, the cross-pollination of both inter-disciplinary and inter-confessional studies has enriched and enlivened all fields of early modern studies, and Anabaptism is no exception.

Although Protestants and Catholics contributed positively to the study of radical Reform movements since the late $1800 \mathrm{~s},{ }^{10}$ it was not until the mid-1900s that Anabaptism, Spiritualism, and various related radical Reform movements were taken seriously in mainstream Reformation research. Radicals became increasingly understood on their own terms, rather than by the condemnatory statements of their persecutors, as had been the common approach in Reformation studies approach until then. Key questions on the unifying identity of these groups had remained largely unresolved; even the doctrine of baptism-whether it required water or the sign of the cross-was disputed among the earliest Anabaptist groups.

9. Two of the leading representatives of this school were Gerhard Zschäbitz, from former East Germany (see “Zschäbitz, Gerhard," accessed 19 December 2014, http://www.mennlex.de/doku.php?id=art:zschaebitz gerhard) and A. F. Mellink from the Netherlands (see "Mellink, Albert Frederik," accessed 19 December 2014, http://www.mennlex.de/doku.php?id=art:mellink_albert_frederik\&s[]=mellink).

10. For example, the Austrian Catholic scholar Johann Loserth, the German Protestant Alfred Hegler (a scholar of Spiritualism), and Ernst Troeltsch (whose study of sectarian history led to a theoretical shift). 
Yet, despite the increasing integration of Anabaptism into Reformation studies, a group of primarily American Mennonite historians in the 1900s-led by the Mennonite churchman and historian Harold S. Bender, and commonly called the "Bender school"-constructed a version of Anabaptist origins in an attempt to use the study of Mennonite origins to prove the exclusive truth of their theological orientation. This, in turn, led to controversies in Anabaptist studies over the relationship between academic rigour and denominational or ideological commitment, and since the 1960s progress in creating an interconfessional and interdisciplinary approach has become clearly evident, particularly in Canada.

In 1962, the Harvard church historian George H. Williams, a Unitarian, created a conceptual distinction between the "Magisterial Reformation" on the one hand-meaning reform efforts in various territories that were supported or enforced by a political authority, or the civil magisterium-and the movements jointly called the "radical Reformation" on the other. In the latter case, individuals or groups either rejected the magisterial option or simply did not gain adequate political sympathy to implement their reforming agenda. ${ }^{11}$ The radicals had no qualms about theologically condemning the magisterial traditions; they were systematically persecuted for centuries in some regions, a fact that at times has continued to colour the scientific discourse between scholars of differing traditions. Arguably, Williams's use of the term "radical" has come not only to encompass the three types he delineated, namely, Anabaptism, Spiritualism and "Evangelical Rationalism"; radicalism stemming from the Reformation more broadly can be construed to include Sacramentarians, anti-Trinitarians or Unitarians, and the various subsequent groupings such as Mennonites, Hutterites, Socinians, Collegiants, various "Brethren" groups, and even Quakers.

The following study provides an overview of the critical role of Canadian scholars in the past generations and the degree to which some have moderated the discourse between "secular" or "profane" and "ecclesiastical" or "theological" approaches to this sub-field; in effect, this role has also tended to modify the constructed categories in which Anabaptism and Spiritualism or Pietism were 
counter-opposed in previous scholarship. It also traces key controversial issues within the study of Anabaptism, in which Canadians took the lead, both as revisionists and as moderators of widespread debates that have significantly shaped the entire field of study.

After a brief introduction to the evolution starting in the 1960s of Anabaptist studies in Canada, the second section will list the academic genealogies of several Canadian scholars and their major contributions, with a particular focus on Waterloo ${ }^{12}$ and Queen's as centres of influence. The third section will outline the main controversies in Anabaptist studies over the past half-century and the leading roles of Canadians. The topics and controversies to be noted will include the tension between Spiritualism and Biblicism as defining elements of Anabaptism, the "poly-genesis thesis" controversy of the 1970s, the modification of that thesis in the 1990s, the resurfacing of the controversy between 2003 and 2006, and the contributions by Canadians. The "Marpeck renaissance" in which Canadians have made an exceptionally significant contribution will not be discussed separately in section 3; rather, the major Canadian contributions to the rediscovery in the 1950s of Pilgram Marpeck as leader of an Anabaptist network from the late 1520s to the 1550s will be described piecemeal throughout section 2. The final section provides a brief overview of a few current (and major) projects led by Canadian scholars, and of some noteworthy recent international contributions to the field. Throughout this overview, with a few exceptions, only monographs will be noted. ${ }^{13}$

\section{Controversies over Anabaptist origins and identity: 1920s-1950s}

In the first half of the twentieth century a new orientation of Anabaptist historical scholarship developed, primarily among Mennonites in the United States. This approach sought to more fully align the study of Anabaptism with the theological interests of contemporary Mennonites, who saw themselves as the heirs to certain aspects of Anabaptism. In 1927, Bender founded the Mennonite Quarterly Review in Indiana. The $M Q R$ became the foremost English-language scholarly journal for Anabaptism, broadly including Mennonite history,

12. By Waterloo as a "centre of influence" is meant the region including the universities of Wilfrid Laurier and Waterloo, with their affiliated religious colleges.

13. Dissertations are referenced only if they are unpublished; otherwise the published work is cited. 
theology, and radical Reformation studies generally, and even the study of Spiritualism and Pietism to a lesser degree. In partnership with other leading Mennonite scholars such as John Horsch, J. C. Wenger, and Robert Friedmann, Bender narrowly defined the essence of Anabaptism such as to align the historic origins of Mennonites with their favoured contemporary theological and ethical orientation. The so-called "Bender school" defined genuine Anabaptists as only those who were baptized as adults and who had a Biblicist basis for their faith and practice. According to this school of thought, such "Evangelical Anabaptists" stood in opposition to both Pietism and Spiritualism, which can be seen as overly individualistic. In his landmark essay, "The Anabaptist Vision" (1944), Bender famously defined Anabaptists as pacifists who were baptized as adults into a fellowship of believers, all of whom considered discipleship (Nachfolge Christi) a feature of Christian practice sine qua non. ${ }^{14}$ This effectively marginalized or excluded any Anabaptists who exhibited "Spiritualist" tendencies, meaning those who de-emphasized or denigrated the value of eternal practices (the "outer") in favour of spirituality (the "inner"). It also categorically excluded those whose apocalyptic fervour led them to support violent revolt, most notably those connected with the peasants' revolt of the mid-1520s and the Münsterite rebellion of the mid-1530s, which were numerically significant elements of early Anabaptism. In this way, the Bender school gave scant attention to Balthasar Hubmaier, the academic theologian of early Anabaptism who rejected the pacifist-nonresistant current. Over the course of the succeeding decades, Hubmaier's central role in shaping early Anabaptism was debated hotly, and this eventually led to a revised conception of the unity and diversity of early Anabaptism.

\section{Genealogies, institutions, and centres of influence}

The 1960s witnessed the sudden growth of multiple centres in Canada where studies of radical Reform, particularly Anabaptism, flourished. In 1964, Walter Klaassen, a Mennonite, was the first of this new generation to begin teaching and scholarship in Canada. His chaplaincy and teaching positions at Conrad 
Grebel, ${ }^{15}$ the Mennonite college at the University of Waterloo, ended with his retirement in 1987. Klaassen was soon followed in 1968 by Kenneth Davis, a Baptist, who began a teaching position at UWaterloo. That same year, James M. Stayer, originally raised River Brethren (Brethren in Christ) in Pennsylvania, began teaching at Queen's and became an outspoken critic of the theologicallydriven approach to the study of Anabaptism that dominated in the United States. Also in 1968, Jarold K. Zeman (2000†), a Baptist, began teaching at Acadia Divinity College in Wolfville, Nova Scotia, a position he held until his retirement. Subsequently, two official centres were established for the study of Anabaptism, both presently active: the Acadia Centre for Baptist and Anabaptist Studies, ${ }^{16}$ and the Institute for Anabaptist and Mennonite Studies ${ }^{17}$ at Conrad Grebel. However, in terms of influence, Queen's and UWaterloo became the most prominent institutions; their mentorship of graduate students and their publishing efforts have shaped the study of Anabaptism internationally.

Klaassen and Stayer - the two scholars who initially shaped these centres of influence-are both now retired but remain active in scholarship. At Conrad Grebel and Queen's they were critically engaged in historical-theological scholarship, Klaassen also being active in the religious life of his Mennonite denomination, Stayer declaring himself a "profane" historian. Both ably handled radical Reformation sources in Latin, German, and Dutch-and alongside their scholarly studies also published translations of original sources. Somewhat predictably perhaps, Klaassen's influence among his students has led, now two generations later, to a continued symbiosis between the contemporary interests of the Mennonite Church and a reflection upon its origins in the radical Reformation. This generally positive relationship between church and academy is also a feature of Stayer's sphere of influence to some degree, although his critical study of Anabaptism has sought to avoid the entanglement of scholarly and church interests; and while Stayer and some of his students have been accused by denominationally-committed scholars of having a secular bias that

15. Now named Conrad Grebel University College, it is affiliated with the Mennonite Church of Eastern Canada and contains a wealth of Mennonite archival collections as well as radical Reformation materials and research aids.

16. "Acadia Centre for Baptist and Anabaptist Studies," accessed 19 December 2014, http://libguides. acadiau.ca/ACBAS_Home.

17. “Institute of Anabaptist and Mennonite Studies," accessed 19 December 2014, https://uwaterloo.ca/ grebel/academics/continuing/institute-anabaptist-and-mennonite-studies. 
distorted their scholarship (see Strübind below), they have invariably enjoyed collegial relations with scholars of Anabaptism worldwide and indeed have become leaders in the critical study of Anabaptism. The story of a distinctively Canadian contribution to Anabaptist research began with the tenure of Walter Klaassen at Conrad Grebel.

\section{Klaassen at Waterloo: theologically-moderating orientation}

The historical Mennonite settlement of the Waterloo region is also host to a large Lutheran community, and Anabaptist scholarship in Waterloo has seen a productive inter-confessional engagement among Baptists, Mennonites, and Lutherans, and others. The theological examination of the early movement and its relationship with traditions that emerged (Hutterite, Mennonite, Baptist, etc.) has continued to play a central role, both concerning Anabaptist origins and its normative character, but also the basic question of the Biblicism of early Anabaptists, a movement that was also strongly shaped by Spiritualism.

Walter Klaassen's unpublished dissertation (Oxford, 1960) remains to the present much overlooked as a guide to the relationship between Spiritualism and Anabaptism, as well as the development of Anabaptist biblical hermeneutics. ${ }^{18}$ This topic signalled his life-long interest in socio-political issues and scriptural hermeneutics, as particularly evidenced in his extensive work on the Anabaptist leader Pilgram Marpeck, whose biblical hermeneutics have been the subject of numerous studies. Connected with the question of hermeneutics, Klaassen examined apocalypticism in the radical Reformation. ${ }^{19}$ His teaching role at Conrad Grebel enduringly shaped that academic community as a centre of excellence in Anabaptist research. Most influential among his publications are his lectures, collectively entitled Anabaptism: Neither Catholic nor Protestant, which became a classic summary of the shift away from the understanding of Anabaptism as the true or logical fulfillment of the Protestant Reformation; the lectures conceived of Anabaptism in its own terms as a tertium quid, in contrast to both Catholic Reform and Protestantism, while still recognizing its debt to both traditions. ${ }^{20}$ This approach liberated some Mennonites, and

18. Walter Klaassen, "Word, Spirit and Scripture in Early Anabaptist Thought" (DPhil thesis, Oxford, 1960).

19. Walter Klaassen, Living at the End of the Ages: Apocalyptic Expectation in the Radical Reformation (Lanham, MI: University Press of America, 1992).

20. Walter Klaassen, Anabaptism: Neither Catholic nor Protestant (Waterloo, ON: Conrad Press, 1973). 
others who identified with the Anabaptist tradition, to explore more honestly the multiple aspects of their radical Reformation origins, being less encumbered by the theological agenda of Protestantism. This orientation has led some Mennonites, for example, to explore more deeply the connection between late medieval asceticism and Reform movements within Catholicism, as well as Renaissance humanist influences, primarily in connection with Erasmus (see especially Abraham Friesen, below), that shaped many of the early leaders of Anabaptism. As a testament to its popularity, Anabaptism: Neither Catholic nor Protestant is still in print after forty years.

Demonstrating his research interests beyond the traditional Swiss, south German, and Dutch regions where Anabaptism developed, in the late 1970s Klaassen published a study of the revolutionary Tyrolean (non-Anabaptist) radical reformer Michael Gaismair. ${ }^{21} \mathrm{He}$ also published translations of Anabaptist sources over the years, most notably in his partnership with William Klassen in The Writings of Pilgram Marpeck, ${ }^{22}$ and also his Anabaptism in Outline, a topically organized collection of Anabaptist texts, which is still widely consulted ${ }^{23}$ In connection with this theme, Klaassen also completed a draft translation of Melchior Hoffman's Commentary on Revelation (1530), which I am currently preparing for publication, along with translations of Hoffman's contemporaneous apocalyptic writings. More recently Klaassen partnered with Klassen in writing a biography of Pilgram Marpeck. The book offers a portrait of this Anabaptist leader as one committed to moderating the extreme positions of his day (Legalism and Spiritualism); who attempted to develop a political ethic of engagement in contrast to the separatist nonresistance of other Anabaptist groups. ${ }^{24}$ While taking apocalypticism seriously as a key element in early Anabaptism, along with his effort to hold Biblicism and Spiritualism in tension as non-exclusionary features in Anabaptist hermeneutics, Klaassen's scholarship, which places a high emphasis on theological analysis, has provided a moderating orientation that has carried through to subsequent generations of scholarship at Waterloo.

21. Walter Klaassen, Michael Gaismair: Revolutionary and Reformer (Leiden: Brill, 1978).

22. Walter Klaassen, Werner Packull, and John Rempel, eds. and trans., Later Writings by Pilgram Marpeck and His Circle (Kitchener, ON: Pandora Press, 1999).

23. Walter Klaassen, ed., Anabaptism in Outline (Kitchener, ON: Herald Press, 1981).

24. Walter Klaassen and William Klassen, Marpeck: A Life of Dissent and Conformity (Waterloo: Herald Press, 2008). 


\section{Stayer at Queen's: social-political (non-confessional) orientation}

Anabaptism as a socio-political and revolutionary movement has been the primary theme of Stayer's published work; however, the range of his research has encompassed nearly the entire field of Anabaptism and, through his mentorship of students, he has influenced the field of Reformation radicalism more generally. While studying at Cornell University (PhD, 1964), he developed a critical orientation that differed sharply from the denominationally-committed approaches of the Bender school. His dissertation, published as Anabaptists and the Sword (1972), signalled his efforts to offer an honest evaluation of the political nature and ideology of early Anabaptism, which clearly demonstrated the connection between the Peasants' War and the rise of early Anabaptism. ${ }^{25}$ The previous claim that, aside from some exceptions, "evangelical Anabaptism" was generally nonresistant from the start became untenable in the wake of Stayer's book. His engagement with key European scholars led to his shift toward social history, notably the German historians Hans-Jürgen Goertz and Martin Haas, ${ }^{26}$ whose studies of Anabaptism in the late 1520s led to the development of a "two-stage" thesis of the development of the Anabaptist political ethic of separation and nonresistance. Contrary to the thesis that a single, monogenetic origin (Grebel) led consistently to the articulation of an apolitical ethic of separation from the world and nonresistance as articulated in the Anabaptist articles written in Schleitheim in 1527, Stayer and other proponents of the two-stage thesis explained the general evolution of nonresistance as a failure to achieve reforms either through violent revolution or by influencing magisterial reforms. Nonresistance was not to be considered a necessary part of the genetic makeup of the early rise of Anabaptism. This issue would be revisited in the "Strübind controversy" in 2003-06 (see below).

Stayer's second monograph on Anabaptism appeared in the mid-1990s and examined socio-political aspects of the early Anabaptist movement in southern Germany, whereby the practice of community of goods emerged as an adaptation of the failed ideals of the peasants in the mid-1520s. ${ }^{27}$ Due to

25. James Stayer, Anabaptists and the Sword (Lawrence, KS: Coronado Press, 1972); the 1976 edition includes "Reflections and Retractions."

26. Martin Haas, “Der Weg der Täufer in die Absonderung," in Umstrittenes Täufertum 1525-1975: Neue Forschungen, ed. Hans-Jürgen Goertz (Göttingen: Vandenhoeck \& Ruprecht, 1975), 50-78.

27. James M. Stayer, The German Peasants' War and Anabaptist Community of Goods (Montreal: McGill-Queen’s University Press, 1991). 
his continuing contribution in terms of articles, reviews, and until recently his mentorship of graduate students, Stayer is still considered by many the dean of Anabaptist studies in North America.

Describing himself as a "profane historian," throughout his writings Stayer has offered the strongest criticism of some confessionally-committed contemporaries, especially the Mennonite historian and biblical-ethicist John H. Yoder, alongside other American Mennonites of the Bender school. Stayer's recent article on the historiography of Anabaptism published in the Mennonitisches Lexikon succinctly states his critique of the ideological orientation of some American scholars in the field:

It is not the case that accurate, appreciative historical accounts of the Anabaptist movement had to wait for the twentieth-century and came chiefly from the United States with its religious pluralism and separation of church and state. It is true that in the sixteenth century Anabaptism was subjected to fifty years of religious persecution and that it was made a capital crime in the Holy Roman Empire in 1529. However, from the sixteenth century onward important historical accounts of Anabaptism were written either by its adherents or at least by persons who had no sympathy with its persecutors. ${ }^{28}$

Throughout their careers both Klaassen and Stayer established a critical yet moderating tone in Anabaptist scholarship in Canada, such that those who declared their theological convictions to be aligned with that of their subjects were welcomed alongside those who had no confessional affinity to Anabaptists whatever.

28. Cited above is the English original from the author. The published version reads, "Es ist keineswegs so, dass sorgfältige, den täuferischen Bewegungen des 16. Jahrhunderts gewogene Darstellungen bis ins 20. Jahrhundert warten mussten und hauptsächlich in den Vereinigten Staaten von Amerika entstanden, wo religiöser Pluralismus und Trennung von Kirche und Staat in der Verfassung verankert sind. Wohl war es so, dass das Täufertum in den ersten fünfzig Jahren seiner Entwicklung religiöser Verfolgung ausgesetzt und 1529 sogar zum Kapitalverbrechen im Heiligen Römischen Reich erklärt worden war. Danach wurden aber wichtige bedeutende historische Darstellungen des Täufertums entweder von seinen Anhängern oder von Autoren geschrieben, die keinerlei Sympathie für die Verfolger der Täufer aufbrachten." See James Stayer, “Täuferforschung," Mennlex, ed. Hans-Jürgen Goertz, accessed 19 December 2014, http://www.mennlex.de/doku.php?id=top:taeuferforschung\&s[]=historiographie. 


\section{A note on mentorship: Queen's and UWaterloo}

Since the 1970s, UWaterloo and Queen's have been unrivalled nationally, perhaps internationally, in terms of the quantity and quality of their mentorship of graduate students and supervision of doctoral dissertations in Anabaptistrelated studies. Graduate student mentorship has been a particular strength at Queen's, where James Stayer was a supervisor to several doctoral students in Anabaptism and Reformation radicals. However, already in the 1980s, his doctoral student Werner O. Packull became a bridge between Queen's and UWaterloo, providing these distinct institutions with an even greater degree of coherence.

\section{Packull: between Queen's and UWaterloo}

Packull, a Lutheran, began his studies at UWaterloo studying under Davis, then pursued doctoral studies with Stayer on mysticism in early Anabaptism. This latter mentorship led to a life-long collegial relationship. ${ }^{29}$ In 1974, Packull was hired at Renison College (Anglican), UWaterloo and in 1983 was hired at Conrad Grebel. Although Klaassen and Stayer already enjoyed a high degree of compatibility, Packull's (non-Mennonite) mentorship and scholarship significantly increased the coherence of these two Canadian centres of research, and therefore indelibly shaped the future of Canadian Anabaptist scholarship for three decades until he retired in 2003.

Reflecting the interests of Davis, Packull's dissertation had explored the medieval roots of south German Anabaptism, including those often considered Spiritualist Anabaptists. ${ }^{30}$ Later, his research into the broad denomination-like network of Anabaptists from the late 1520s well into the 1530s-in which Marpeck's role was highlighted-resulted in a modified theory of Anabaptist inter-relatedness. Packull described how the diverse regions where Anabaptism developed had much greater commonality and were networked more intricately than he and others in the mid-1970s had suggested (see below, "Theory

29. An early collaborative project-The Anabaptists and Thomas Müntzer, trans. and ed. James Stayer and Werner Packull (Toronto: Kendall/Hunt, 1980)_introduced several short studies that were otherwise unavailable in English.

30. Werner Packull, Mysticism and the Early South German-Austrian Anabaptist Movement 1525-1531 (Kitchener, ON: Herald Press, 1977). 
of Origins"). ${ }^{31}$ In 1995, his book Hutterite Beginnings established a new conceptual framework of the interdependent nature of diverse Anabaptist groups throughout Europe. Packull also published a study of Peter Riedemann, the key founder of the Hutterite tradition. ${ }^{32}$

Packull's influence as a mentor at UWaterloo was similar to Stayer's in its far-reaching impact. Already in the 1980s Packull supervised dissertations, mentoring some of the scholars who became leaders in Anabaptist and also Pietist studies. His doctoral students, who were from diverse confessional backgrounds, made contributions to radical Reformation studies; among the most prominent are Charles Nienkirchen (1985), Gary Waite (1986), James Coggins (1986), Douglas Shantz (1986), and Edmund Pries (1988).

Nienkirchen, professor of Christian history and spirituality at Ambrose University College in Calgary, Alberta, studied the early ecclesiology of Anabaptism. ${ }^{33}$ Waite is a professor of early modern history at the University of New Brunswick, Fredericton, and has been the most active of Packull's students in Dutch Anabaptist and Spiritualist scholarship, ${ }^{34}$ including contributions to two Brill collections in 2014. ${ }^{35}$ Shantz holds the Research Chair in Christian Thought at the University of Calgary. He has focused on the Spiritualist and Pietist movements stemming from the Reformation period and leading up to the Enlightenment period. Starting with his dissertation on Valentine

31. Werner Packull, Hutterite Beginnings: Communitarian Experiments during the Reformation (Baltimore: Johns Hopkins University Press, 1995).

32. Werner Packull, Peter Riedemann: Shaper of the Hutterite Tradition (Kitchener, ON: Pandora Press, 2007).

33. Nienkirchen's UWaterloo dissertation was titled "In the World but Not of It: The Development of Separatist Motifs in Early Anabaptist Ecclesiology (1523-1528).”

34. Gary Waite, David Joris and Dutch Anabaptism, 1524-1543 (Waterloo, ON: Wilfrid Laurier University Press, 1990). Waite has also contributed a volume of translations: see The Anabaptist Writings of David Joris, trans. and ed. Gary K. Waite (Waterloo, ON: Herald Press, 1994). For his most recent monograph on radical Reformation history, see Eradicating the Devil's Minions: Anabaptists and Witches in Reformation Europe, 1535-1600 (Toronto: University of Toronto Press, 2007).

35. August den Hollander, Alex Noord, Mirjam van Veen, and Anna Voolstra, Religious Minorities and Cultural Diversity in the Dutch Republic: Studies Presented to Piet Visser on the Occasion of His 65th Birthday (Leiden: Brill, 2014); Mirjam van Veen, Piet Visser, and Gary Waite, eds., Sisters: Myth and Reality of Anabaptist, Mennonite, and Doopsgezind Women, ca. 1525-1900 (Leiden: Brill, 2014). 
Crautwald, ${ }^{36}$ the main associate of the Spiritualist Caspar Schwenckfeld (who is also considered the godfather of Pietism), Shantz has become an international leader in the study of Pietism-notably in his comprehensive tome, $A n$ Introduction to German Pietism ${ }^{37}$ - and is the editor of the Brill Companion to German Pietism, 1660-1800 (2014). Pries made a significant contribution to the ongoing discussions about the political ethics of early Swiss Anabaptism, completing both a master's thesis and a doctoral dissertation on the practice concerning the civil oath. ${ }^{38}$ And finally, Coggins wrote a dissertation on the relationship between John Smyth, as the originator of the Baptist movement, and Dutch Mennonites. ${ }^{39}$

Packull's students continue to broaden the scope of radical Reformation and Anabaptist studies, signalling a continued collaboration among scholars of diverse confessional backgrounds.

\section{Queen's graduates}

Stayer's supervisory role at Queen's has had a prolonged impact, not only on Anabaptist studies but also on Spiritualism and radical Reform studies more generally. His graduate students have made significant contributions to radical Reformation research, including Willem de Bakker (MA, 1987), ${ }^{40}$ Geoffrey Dipple (PhD, 1991), ${ }^{41}$ Michael Driedger (PhD, 1996), ${ }^{42}$ Scott Gillies (MA,

36. Douglas Shantz, Crautwald and Erasmus: A Study in Humanism and Radical Reform in Sixteenth Century Silesia (Baden-Baden: V. Kroener, 1992).

37. Douglas Shantz, An Introduction to German Pietism: Protestant Renewal at the Dawn of Modern Europe (Baltimore, MD: Johns Hopkins University Press, 2013).

38.Edmund Preis, "Anabaptist Oath Refusal: Basel, Bern and Strasbourg, 1525-1538” (PhD dissertation, University of Waterloo, 1995).

39. James R. Coggins, John Smyth's Congregation: English Separatism, Mennonite Influence, and the Elect Nation, Studies in Anabaptist and Mennonite History 32 (Scottdale, PA: Herald Press, 1991).

40. Willem de Bakker, "Civic Reformer in Anabaptist Munster: Bernhard Rothmann, 1495?-1535?" (master's thesis, Queen's University, 1987). This thesis also passed as a PhD dissertation at the University of Chicago. Recently Driedger and Stayer revised and expanded de Bakker's thesis into a monograph with updated research on the Münster rebellion; see Willem de Bakker, Michael Driedger, and James Stayer, Bernard Rothmann and the Reformation in Münster, 1530-35 (Kitchener, ON: Pandora Press, 2009).

41. Geoffrey Dipple, Antifraternalism and Anticlericalism in the German Reformation: Johann Eberlin von Guenzburg and the Campaign against the Friars (Brookfield, VT: Ashgate, 1996).

42. Michael D. Driedger, Obedient Heretics: Mennonite Identities in Lutheran Hamburg and Altona during the Confessional Age (Burlington, VT: Ashgate, 2002). 
1996), ${ }^{43}$ Sonia Riddoch (2012†; PhD, 1996), ${ }^{44}$ William McNiel (PhD, 1999), ${ }^{45}$ and Victor Thiessen $(\mathrm{PhD}, 1998){ }^{46}$ Subsequent to completing their PhD studies, Dipple, Driedger and Thiessen have continued to make major contributions to Anabaptism, Spiritualism and early Mennonite historical studies. Dipple, a Lutheran, currently professor of History, Augustana College, Sioux Falls, South Dakota, co-edited with Packull a Festschrift for Stayer ${ }^{47}$ and wrote a study of the conceptions of history in the radical Reformation. ${ }^{48}$ Driedger, professor of History at Brock University, has applied the confessionalization thesis to Anabaptist studies, as found in many recent Reformation studies. ${ }^{49}$ Driedger's major studies have focused primarily on Mennonites in the seventeenth-century period, both in northern Germany ${ }^{50}$ and most recently the revolutionaries in the Dutch Republic, a topic that further extends Stayer's scholarship on revolution and violence in the Anabaptist tradition. Thiessen has been active in teaching roles at Wilfrid Laurier University and Brock University, a recent contribution being the translation of a large number of the texts from the Marpeck Circle's collection Das Kunstbuch. ${ }^{51}$ Thiessen has also continued his study of reform efforts among the lower nobility by applying network theories of communication

43. Scott Gillies, "Huldrych Zwingli and the Zuerich Origins of the Covenant, 1524-1527" (master's thesis, Queen's University, 1996).

44. Sonia Riddoch, “The Ernst Troeltsch-Karl Holl Controversy and the Writing of Reformation History” (PhD dissertation, Queen's University, 1996).

45. William McNiel, "Andreas von Karlstadt and Thomas Muentzer: Relatives in Theology and Reformation” (PhD dissertation, Queen's University, 1999).

46. Victor Thiessen, "Nobles' Reformation: The Reception and Adaptation of Reformation Ideas in the Pamphlets of Noble Writers from 1520 to 1530" (PhD dissertation, Queen's University, 1998).

47. Werner O. Packull and Geoffrey L. Dipple, eds., Radical Reformation Studies: Essays Presented to James M. Stayer (Brookfield, VT: Ashgate, 1999).

48. Geoffrey Dipple, "Just as in the Time of the Apostles": Uses of History in the Radical Reformation (Kitchener, ON: Pandora Press, 2005).

49. Michael Dreidger, "The Intensification of Religious Commitment: Jews, Anabaptists, Radical Reform, and Confessionalization," in Jews, Judaism, and the Reformation in Sixteenth-Century Germany, ed. D. P. Bell and S. G. Burnett (Leiden: Brill, 2006).

50. Michael Driedger, Zuflucht und Koexistenz: 400 Jahre Mennoniten in Hamburg und Altona (Bolanden-Weierhof: Mennonitischen Geschichtsverein, 2001).

51. John D. Rempel, ed., Jörg Maler's Kunstbuch: Writings of the Marpeck Circle (Kitchener, ON: Pandora Press, 2010). 
to his analysis of the early rise and interaction between Protestant nobles and both the Spiritualists, Schwenckfeldian circles, and Anabaptist communities.

\section{Waterloo contributions to Reformation radicalism and Pietism}

Aside from Packull's graduate students, several other scholars in Waterloo have made major contributions to radical Reformation studies. Most notable are Davis, Klassen, Rempel, Snyder, Peter Erb, Linda Huebert Hecht, and Erika Rummel.

In the 1970s the Baptist historian Davis helped to shape Waterloo into a major centre of radical Reformation studies. Later he taught and mentored graduate students at McMaster Divinity School but remained a member of the faculty at UWaterloo where he directed the Reformation History PhD program. His leadership as the co-founder and co-director of the Reformation History Consortium enabled collaboration between Guelph, McMaster, Queen's, and UWaterloo. Davis's dissertation concerning asceticism (University of Michigan, 1971) has resonated with the humanistic and medieval-pietistic orientation of Anabaptist studies to the present. ${ }^{52}$

Klassen, professor emeritus at UWaterloo, was originally Mennonite and later joined the United Church of Canada. As noted above, he partnered with Klaassen in at least two significant Pilgram Marpeck projects: a biography and translations. In fact, he began his career with a dissertation on Marpeck's life, writings, and biblical hermeneutics. ${ }^{53} \mathrm{He}$ spent parts of his career in Winnipeg, Toronto, and Waterloo, and several years outside of Canada, with most of his teaching and publication focusing on New Testament studies.

Erb, originally Mennonite and now Roman Catholic, is another Waterloo scholar and leader in the field of Spiritualism and Pietism. ${ }^{54}$ Professor emeritus of Religion at Wilfrid Laurier University, Erb has translated a collection of

52. Kenneth R. Davis, Anabaptism and Asceticism: A Study in Intellectual Origins (Scottdale, PA: Herald Press, 1974).

53. William Klassen, Covenant and Community: The Life, Writings, and Hermeneutics of Pilgram Marpeck (Grand Rapids, MI: Eerdmans, 1968).

54. Peter C. Erb, Pietists, Protestants and Mysticism: The Use of Late Medieval Spiritual Texts in the Work of Gottfried Arnold (1666-1714) (Metuchen, NJ: Scarecrow Press, 1989). 
Pietistic writings, ${ }^{55}$ including Jakob Boehme, ${ }^{56}$ and remains a leading specialist on the Spiritualist Reformer Caspar Schwenckfeld..$^{57}$

Mennonite historian Snyder was a student of both Davis and Klaassen at UWaterloo and McMaster University. His dissertation (McMaster, 1981) examined Michael Sattler, one of the key figures in the rise of the Swiss Brethren Anabaptist movement. ${ }^{58}$ Snyder later replaced Klaassen at Conrad Grebel, providing significant continuity with Klaassen's theological studies orientation-as a critical scholar open to the insights of secular scholarship, especially concerning social scientific methods, and who saw Spiritualism and Anabaptism in less oppositional terms. With his Introduction to Anabaptist History and Theology (1995), Snyder also began his own publishing house, Pandora Press, which he managed until his retirement from teaching in 2011. ${ }^{59}$ Over the past two decades this publisher has produced more studies and collections of translations focusing primarily on the Anabaptist and Mennonite traditions than any other publisher in Canada. ${ }^{60}$ Demonstrating his debt to Davis and the ascetic orientation of Anabaptism, he also published a monograph on the spirituality of the Anabaptist tradition. ${ }^{61}$ Snyder has recently been preparing another volume of English translations of Anabaptist sources from the later Swiss Brethren tradition. Snyder's contributions to shaping the historiographical debates will be discussed primarily below starting with the "post-polygenesis" approach.

Mennonite historical theologian Rempel began his career as chaplain at Conrad Grebel, working with Klaassen; he currently directs the Toronto Mennonite Theological Centre, where he also mentors graduate students, primarily in theology. His dissertation at the Toronto School of Theology (1986) focused on Anabaptist understandings of the Lord's Supper, featuring a study of

55. Peter C. Erb, ed. and trans., Pietists: Selected Writings (New York: Paulist Press, 1983).

56. Peter C. Erb, Jakob Boehme: The Way to Christ (New York: Paulist Press, 1978).

57. Peter C. Erb, Schwenckfeld in His Reformation Setting (Valley Forge, PA: Judson Press, 1978).

58. C. Arnold Snyder, The Life and Thought of Michael Sattler (Scottdale, PA: Herald Press, 1984).

59. C. Arnold Snyder, Anabaptist History and Theology: An Introduction (Kitchener, ON: Pandora Press, 1995).

60. For example, C. Arnold Snyder, ed., Sources of South German/Austrian Anabaptism, trans. Walter Klaassen, Frank Friesen, and Werner O. Packull (Kitchener, ON: Pandora Press, 2001).

61. C. Arnold Snyder, Following in the Footsteps of Christ: The Anabaptist Tradition (Maryknoll, NY: Orbis, 2004). 
Marpeck's sacramental theology ${ }^{62}$ Subsequent contributions include his role as editor and translator of sources relating to the so-called Marpeck Circle, ${ }^{63}$ and the massive collection of Marpeck-related sources entitled Das Kunstbuch. ${ }^{64}$ In this way he has been a major contributor to the Marpeck renaissance in Anabaptist scholarship alongside Klaassen, Klassen, Packull, Thiessen, and others. His research continues to explore worship and sacraments in the early Anabaptist tradition, ${ }^{65}$ and this scholarship has led to various roles in official ecumenical dialogues, most recently between Mennonites, Lutherans, and Catholics concerning baptism.

Hecht, a Mennonite Brethren and student of Snyder, is another significant contributor to the Waterloo Anabaptist research community, particularly in bringing to light the experiences of women. With Snyder she co-edited a collection of the profiles of Anabaptist women. ${ }^{66}$ She has also developed a database of Anabaptist women in Austria and published a collection of writings about Austrian Anabaptist women, ${ }^{67}$ of whom some, like Helena von Freyberg, had significance for Marpeck's leadership.

Rummel, professor emerita of History at Wilfrid Laurier University, a renowned scholar of Renaissance humanism, has directed the edition and translation project of the letters of the Strasbourg reformer, Wolfang Capito, with elements appearing in print ${ }^{68}$ and online ${ }^{69}$ through the Iter Gateway project. This edition project has contributed significantly to the accessibility of sources concerning leaders of the early Anabaptist and Spiritualist movements who were active in the late 1520 s in Strasbourg.

62. John Rempel, The Lord's Supper in Anabaptism: A Study in the Christology of Balthasar Hubmaier, Pilgrim Marpeck, and Dirk Philips (Waterloo, ON: Herald Press, 1993).

63. Klaassen, Packull, and Rempel, Later Writings by Pilgram Marpeck and His Circle.

64. John D. Rempel, Jörg Maler's Kunstbuch: Writings of the Marpeck Circle.

65. John Rempel, "Anabaptist Theologies of the Eucharist," in A Companion to the Eucharist in the Reformation, ed. Lee Palmer Wandel (Boston: Brill, 2014).

66. Linda Huebert Hecht and C. Arnold Snyder, eds., Profiles of Anabaptist Women: Sixteenth-Century Reforming Pioneers (Waterloo, ON: Wilfrid Laurier University Press, 1996).

67. Linda Huebert Hecht, Women in Early Austrian Anabaptism: Their Days, Their Stories (Kitchener, ON: Pandora Press, 2009).

68. Erika Rummel and Milton Kooistra, The Correspondence of Wolfgang Capito, Vols. 1-2 (Toronto: University of Toronto Press, 2005-09).

69. “The Electronic Capito Project," accessed 19 December 2014, http://www.itergateway.org/capito/. 
The inter-connections between history, sociology, and theology in Waterloo were not exclusively identified and promoted by historians; scholars in other disciplines at Conrad Grebel, such as sociology (Rodney Sawatsky, $2004 \dagger$ ) and theology (A. James Reimer, 2010†), assisted in both echoing and even further nuancing the methodological critiques of historians. Sawatsky's dissertation (1977) $)^{70}$ critiqued the Bender school's "American Mennonite" theological or ideological criteria for defining normative Anabaptism. Reimer, a Mennonite historical theologian at Conrad Grebel and former director of the Toronto Mennonite Theological Centre, also mentored scholars writing historical theological dissertations on Anabaptist topics. Mennonite historical theologian Karl Koop, now professor of History and Theology at Canadian Mennonite University, completed a dissertation in Toronto under the direction of Reimer on the development of Mennonites' confessional traditions, ${ }^{71}$ including a translated edition of historic Anabaptist-Mennonite confessions of faith. ${ }^{72}$ Another PhD student of Reimer's was the Baptist Brian Cooper, currently associate dean at Trinity Western University, whose dissertation (2006) at the Toronto School of Theology examined natural law in Anabaptism, with a particular focus on Marpeck. ${ }^{73}$ Reimer was a strong advocate for a contemporary Mennonite theological orientation that was not beholden to the Bender school's attempt to delineate a normative Anabaptism. Such theological and sociological complements to the critical Anabaptist historical studies at Grebel enabled Waterloo to flourish as a centre of influence, not merely within academia, but especially within contemporary Mennonite studies.

\section{Beyond Queen's and Waterloo: Wolfville, Montreal, and Winnipeg}

Jarold Zeman taught at the Baptist seminary, Acadia Divinity College, Wolfville, Nova Scotia, which did not have a PhD program in Reformation

70. History and Ideology: American Mennonite Identity Definition through History (Kitchener, ON: Pandora Press, 2005).

71. Karl Koop, Anabaptist-Mennonite Confessions of Faith: The Development of a Tradition (Kitchener, ON: Pandora Press, 2004).

72. Karl Koop, ed., Confessions of Faith in the Anabaptist Tradition: 1527-1660 (Kitchener, ON: Pandora Press, 2006).

73. Brian Cooper, "Human Reason or Reasonable Humanity? Balthasar Hubmaier, Pilgram Marpeck, and Menno Simons, and the Catholic natural law tradition" (PhD dissertation, University of St Michael's College, 2006). 
studies and therefore did not produce a level of graduate scholarship comparable to Queen's or UWaterloo. Zeman's dissertation (1966) laid the foundations for the study of Anabaptism in eastern Europe, particularly in Czech, Slovakia, and Moravia. He made pioneering contributions to the eastern European context of Anabaptism and its relationship to other reform groups in that region (Czech Brethren, Hussites, Waldensians).$^{74}$ These crucial studies of the eastern context of the Reformation, and Zeman's identification of Hubmaier as a profound influence on the early development of Anabaptism generally, laid groundwork for the subsequent studies by Packull and the German Baptist historian Martin Rothkegel, ${ }^{75}$ among others, in which the significance of Anabaptism in the regions north of Austria have become integrated into the broader conception of early Anabaptist origins and developments (see "Theories of Origins" below). Arguably, Zeman thus impacted the controversies of both the 1970s and 1990s (described below) by providing a depth of analysis to a geographically broader context, a conception that presupposed the inclusion of Hubmaier as an early leader of Anabaptism with far-reaching influence.

In Montreal, Edward J. Furcha (1997†) taught at McGill University as professor of Religious Studies, where he was a leader in radical Reformation studies with a focus on Zwinglian and Calvinist reform. Notably, he published translations of selected writings from the Anabaptist Hans Denck ${ }^{76}$ and the Spiritualist Sebastian Franck's Paradoxa, ${ }^{77}$ and selections from the early radical Reformer Andreas Bodenstein von Karlstadt. ${ }^{78}$ In Winnipeg, where many Mennonites have focused on aspects of Anabaptist and Mennonite history, most notable is Harry Loewen, a member of the Klaassen-Stayer generation,

74. Jarold Knox Zeman, The Anabaptists and the Czech Brethren in Moravia 1526-1628: A Study of Origins and Contacts (The Hague: Nijhoff, 1969).

75. Martin Rothkegel, "Anabaptism in Moravia and Silesia," in A Companion to Anabaptism and Spiritualism, 1521-1700, ed. James M. Stayer and John D. Roth (Leiden: Brill, 2007), 163-215.

76. Hans Denck, Selected Writings of Hans Denck, ed. and trans. E. J. Furcha (Queenston: Edwin Mellen Press, 1989).

77. Sebastian Franck, 280 Paradoxes or Wondrous Sayings, ed. and trans. Edward Furcha (Lewiston, NY: Edwin Mellen Press, 1986).

78. E. J. Furcha, ed. and trans., The Essential Carlstadt (Waterloo, ON: Herald Press, 1995). 
who wrote an MA thesis (University of Manitoba, 1961) on Luther and the Radicals. $^{79}$

Additional contributions to Anabaptist studies have been made in these institutions and elsewhere in Canada, which the present study has not room to mention. The particular contribution of Canadians to the question of revising the theory of Anabaptist origins speaks much for the leadership of Canadian scholars internationally.

\section{Canadian contributions to controversies}

Historiographic debates in Anabaptist studies in recent decades have seen Canadians playing leading roles in both their instigation and resolution. Starting with Klaassen's protest against the Bender school's demarcation of Anabaptism as non-Spiritualist and non-apocalyptic in the 1960s, the so-called "polygenesis thesis" in the mid-1970s will be discussed below. A further paradigmatic shift came in the mid-1990s when that thesis was modified by some of the same Canadian scholars who pioneered the revisionist shift of the 1970s. And again a decade later (ca. 2003-07), Canadians played a major role in the debate-once again, about early Anabaptist origins-which was re-opened by the German Baptist scholar Andrea Strübind. Scholars at UWaterloo and Queen's have both led and to a large degree resolved these debates.

\section{Spiritualism, Biblicism, and Apocalypticism}

After the death of Bender in 1962, the same year in which Williams's Radical Reformation tome appeared, Klaassen became an early critic of the Bender school's notion of a normative Anabaptism. Klaassen wrote in the MQR addressing the relationship of Biblicism and Spiritualism, which the Bender school and Williams had understood as oppositional factors or influences in early Anabaptism: "One has the disturbing feeling that by 'evangelical Anabaptism' is meant Anabaptism as it ought to have been, seen through the spectacles of twentieth-century wishful thinking, rather than as it actually was." ${ }^{80}$ While accepting the term radical Reformation, he criticized the

79. Harry Loewen, Luther and the Radicals: Another Look at Some Aspects of the Struggle between Luther and the Radical Reformers (Waterloo, ON: Wilfrid Laurier University, 1974).

80. Klaassen, “Spiritualization of the Reformation," Mennonite Quarterly Review 37.2 (1963): 69. 
views of both Bender and Williams alike, asserting that "the tacit assumption that Biblicism and Spiritualism are in some way opposites [... is] basically erroneous." ${ }^{11}$ The tension between these presumed "opposites" was a central issue in early Anabaptism, as his dissertation had sought to clarify. Klaassen's subsequent studies in Anabaptist and Spiritualist apocalypticism have provided further nuance to the relationship between biblical-spiritualist hermeneutics and the apocalyptic fervour of the early Reformation period and scholars such as Stayer, Snyder, Packull, Dipple, and others have continued to explore the connections between these theological directions within early Anabaptism.

\section{Theories of origins: from monogenesis to polygenesis and beyond}

In 1975, Stayer and Packull, along with the German social historian Klaus Deppermann (1990†), published a programmatic article, "From Monogenesis to Polygenesis: The Historical Discussion of Anabaptist Origins" in $M Q R{ }^{82} \mathrm{It}$ focused on what Williams and others already recognized in the 1960s, namely, that not all Anabaptist movements originated from Zurich. Rather, there were centres of unique identity formation in southern Germany around Augsburg (1526) and northern Germany around Emden (1530) that did not stem from the earliest "re-baptizers" in Zurich connected with Conrad Grebel (considered to be the first Anabaptist). Regions outside of Switzerland were no longer to be measured by the articles of faith written at Schleitheim in 1527, in which a sectarian or separatist ethic was pronounced; therefore, the authenticity of those who differed from Schleitheim should no longer be judged against this measure. According to the polygenesis theory, movements that rightly bore the title "Anabaptist" by virtue of practising adult baptism (or re-baptism) cannot be considered illegitimate permutations or corruptions of an essential, original ideal. Rather, there were multiple, relatively independent and unconnected centres of Anabaptist origin, and these also deserve to be studied as Anabaptists without reference to a theological norm.

In contrast to what the Bender school presented as a monogenetic theory of origins, the polygenesis theory was from that point forward accepted nearly universally as a consensus. Stayer has recently shared selections of his written

81. Walter Klaassen, "Spiritualization of the Reformation," 69.

82. James Stayer, Werner Packull, and Klaus Deppermann, "From Monogenesis to Polygenesis: The Historical Discussion of Anabaptist Origins," MQR 49 (April 1975): 83-122. 
memoirs concerning some of the impact of his engagements with scholars like Hans-Jürgen Goertz, Martin Haas, and others in his methodological development. $^{83}$

The debate over origins partly concerned the utility or convenience of creating normative theological categories for the sake of modern Mennonite interests, and the problem of identifying a degree of unity in the Anabaptist movement, while still acknowledging the vast differences between early leaders and regional movements. Subsequently, by the 1990s these same scholars, aided by Arnold Snyder among others, began to refine the broad conception of the movement, exploring the degree and manner in which the diverse movements did contain commonalities - although nonresistance, a tenet Bender and others had delineated as essential to normative Anabaptism, was not included as a core feature.

Although Canadians of various confessional backgrounds played leading roles in the deconstruction and dismantling of the notion of evangelical Anabaptism, there have also been efforts by Canadians to propose alternative notions of Anabaptist normativity; some have published studies with potential to reopen debates concerning the origins of Anabaptism. While Bender promoted the Swiss Zwinglian Conrad Grebel as the father of Anabaptism in his dissertation (1936), ${ }^{84}$ alternative "fathers" or "godfathers" of Anabaptism have been proposed. Presbyterian historian Calvin A. Pater $(2012 \dagger)$ was a graduate from Harvard, a doctoral student of Williams, and later chair of Church History at Knox College, University of Toronto from 1978 until his retirement in 2005. His dissertation sought to demonstrate the primary role played by Andreas Karlstadt in the rise of Anabaptism..$^{85}$ Subsequently Pater also proposed Gerhard Westerburg as the "father" of Anabaptism. ${ }^{86}$ Abraham Friesen, professor emeritus of History at the University of California, Santa Barbara, and a Mennonite Brethren born in Manitoba, began his academic career at Stanford (PhD, 1967)

83. James M. Stayer, "Forschungsurlaub in Zürich 1974/75," Mennonitische Geschichtsblätter (2014): 171-82.

84. Harold S. Bender, Conrad Grebel, c. 1498-1526: The Founder of the Swiss Brethren, Sometimes Called Anabaptists (Goshen, IN: Mennonite Historical Society, 1950).

85. Calvin Pater, Karlstadt as the Father of the Baptist Movements: The Emergence of Lay Protestantism (Toronto: University of Toronto Press, 1984).

86. Calvin Augustine Pater, "Westerburg: The Father of Anabaptism. Author and Content of the Dyalogus of 1527," Archiv für Reformationsgeschichte 85 (1994): 138-62. 
working on the Marxist interpretation of the Reformation. He has also contributed to the study of Thomas Müntzer ${ }^{87}$ and has focused in several publications on the question of Erasmus's connection to the rise of Anabaptism. ${ }^{88}$ The question of whether Karlstadt, Westerburg, or Erasmus could in some sense be the father or godfather of Anabaptism signaled a return to the question of a unified theory of the theological origins of Anabaptism, but these studies have not had a significant impact on historiographic debates concerning the rise and spread of the re-baptizing movement.

\section{"Post-Polygenesis"}

In Snyder's Anabaptist History and Theology: An Introduction (1995), he introduced a "post-polygenesis approach," recognizing the theological interdependence of various Anabaptist groupings. In general, he accepted the critiques of the revisionists of the 1970s; however, partly based on Packull's research in the early 1990s, Snyder argued that an adequate degree of theological coherence did exist between various Anabaptist groups such that one could again speak of an integrated or inter-connected movement emerging from the Swiss Reformation. Snyder proposed fundamental, shared criteria, considered common among early Anabaptist groups, which took seriously the theological influence of Hubmaier - who did not hold to the doctrine of nonresistance. This generally confirmed Stayer's earlier conclusions on that issue. Also, Snyder's affirmation of Spiritualist elements as legitimate within various Anabaptist regional groupings demonstrated the degree to which he shared the position of his mentor, Walter Klaassen, concerning the relationship between Spiritualism and Anabaptism.

\section{Recent controversy: revisionism and the polygenesis thesis}

In 2003, the Baptist German historian Andrea Strübind, currently dean at the University of Oldenburg, Germany, published her dissertation, Eifriger als Zwingli, a major study in which she closely analyzed the rise of Swiss Anabaptism

87. Abraham Friesen, Thomas Muentzer, a Destroyer of the Godless: The Making of a Sixteenth-Century Religious Revolutionary (Berkeley: University of California Press, 1990).

88. Abraham Friesen, Erasmus, the Anabaptists, and the Great Commission (Grand Rapids: Eerdmans, 1998); Abraham Friesen, Reformers, Radicals, Revolutionaries: Anabaptism in the Context of the Reformation Conflict (Elkhart, IN: Institute of Mennonite Studies, 2012). 
in Zurich and St. Gall from 1520 to $1527 .{ }^{89}$ She rejected the notion of a twophase development of Anabaptist separatism, as formulated in the mid-1970s by Stayer, Packull, Deppermann, Goertz, and Haas, and further confirmed by Snyder. Instead, she argued for a consistent trajectory that unified the separatist ecclesiology as stated in 1524 by the "proto-Anabaptists" (Grebel et al.), which aligned with the Schleitheim articles of 1527. She was particularly critical of Hans-Jürgen Goertz and others like Stayer, Packull, and Snyder, who had given greater weight to social criteria in defining the early origins of Anabaptism. Stayer responded with a critical review essay, ${ }^{90}$ and Snyder undertook a thorough re-reading of the relevant sources, which he published as a book-length journal article in 2006, a rebuttal amounting to 143 pages in the $M Q R,{ }^{91}$ which included additional responses from several North American scholars, mostly Mennonites. Snyder once again focused on Balthasar Hubmaier as the major theological leader in the Swiss territories. He also argued for a significant degree of cooperation between Grebel and Hubmaier as the key shapers of Anabaptist ecclesiology and the doctrine of baptism among the Swiss radicals during those years. He argued that if Hubmaier is to be considered not only a legitimate Anabaptist leader but a key theological source for the broader tradition, then his role as an early leader cannot be marginalized or bracketed as both Bender and Strübind had done-despite the inconvenience of his justification of violent resistance for contemporary pacifists, whether Baptist or Mennonite. Concerning the tenor and tone of the controversy, Stayer's review of Strübind's approach in Eifriger als Zwingli reflects on the manner in which scholarly challenges arose in the past, in which Stayer himself played the role of critic:

It remains to register a doubt as to whether "paradigm change" and the clash of warring perspectives is the best way to understand the course of Anabaptist studies. The gentle openness of Mennonite historians like John Oyer and Walter Klaassen at the time of the generational change in the 1970s spared the field of much of the abrasiveness of comparable

89. Andrea Strübind, Eifriger als Zwingli: Die frühe Täuferbewegung in der Schweiz (Berlin: Duncker \& Humblot, 2003).

90. James Stayer, “A New Paradigm in Anabaptist/Mennonite Historiography?" MQR 78 (April 2004): 297-307.

91. C. Arnold Snyder, “The Birth and Evolution of Swiss Anabaptism (1520-1530)," MQR 80 (October 2006): 501-645. 
disciplines. [...] Given time, researchers of my generation have developed a greater appreciation of some of the insights of our elders [...] With Andrea Strübind we have a new, combative, somewhat abrasive voice entering into our discussions. [...] She is to be welcomed by us aging "revisionists"; she is deserving of the same forbearance with which John Oyer and Walter Klaassen, then editors of The Mennonite Quarterly Review, greeted us in the 1970s. ${ }^{92}$

There are no serious contentions or rebuttals in this debate currently, yet given some unresolved and possibly unresolvable questions concerning the early rise of Anabaptism, there is good potential to stir debate in the future. However, with Stayer's reflections on the state of research and the request that even the most critical voices should be heard, this field of study stands to benefit from the engaging yet moderating approach of several colleagues in Canada and elsewhere.

\section{Recent and ongoing contributions}

Over the past decade there have been several noteworthy developments internationally, including a conference in 2006 concerning Anabaptism that took place in Göttingen, Germany. The Canadian presenters included Waite, Snyder, Thiessen, Stayer, and Driedger, all of whom contributed papers to the proceedings, co-edited by Driedger. ${ }^{93}$

Digital encyclopedia resources concerning Anabaptism have been in development since the 1990s. The main English encyclopedia reference tool for Anabaptist research since the 1950s has been the Mennonite Encyclopedia, which was an adaptation and extension of the German Mennonitisches Lexikon (vols. 1-4, 1913-67). This collection was translated and expanded into the Mennonite Encyclopedia (vols. 1-4, 1955-59), to which a fifth volume was added in 1990. In the mid-1990s the Mennonite librarian and archivist at Conrad Grebel, Sam Steiner, directed a project to digitize the articles in the English-language Mennonite Encyclopedia. More recently that initiative

92. James Stayer, “A New Paradigm," 306-07.

93. Anselm Schubert, Astrid von Schlachta, and Michael D. Driedger, eds., Grenzen des Täufertums: Neue Forschungen: Beiträge der Konferenz in Göttingen vom 23.-27.08.2006 = Boundaries of Anabaptism (Gütersloh: Gütersloher Verlagshaus, 2009). 
has grown into an expanding project called GAMEO, the Global Anabaptist Mennonite Encyclopedia Online (www.gameo.org), with an international board of directors, with Steiner now playing the role of associate managing editor. Since 2011, Hans-Jürgen Goertz has edited Mennonitisches Lexikon volume 5 (www.mennlex.de), divided into three parts, of which 5.1 ("People") and 5.2 ("History, Culture, Theology") have been completed. Part 5.3 ("Expansion, Congregations, Organizations") is currently underway. The articles, many of which are written by Canadians, are extensive summaries of research and provide updated literature references that are currently only available in German. No plans have been announced for these to appear in English in GAMEO.

In the United States there has been a recent publishing development of significance to radical Reformation studies. At Penn State University Press, the American Moravian scholar Craig D. Atwood is editing a new series called Pietist, Moravian and Anabaptist Studies, which includes the trans-Atlantic world as well. The first volume in the series, Mystical Marriage and the Crisis of Moravian Piety in the Eighteenth Century, by Paul Peucker, is scheduled to be released in June 2015.

Additional upcoming projects involving Canadian scholarship include Mennonites in Dialogue: Official Reports from International and International Ecumenical Encounters, 1975-2012, co-edited by me (a Canadian Mennonite) and the German Mennonite theologian Fernando Enns. ${ }^{94}$ This collection provides English editions of ecumenical dialogues involving Mennonites over the last forty years. Most of these involved the efforts of historians and other scholars to interpret matters of difference stemming from the Reformation, for example, the persecution of Anabaptists and their official condemnations as stated in confessional documents such as the Lutheran Confessio Augustana.

If Williams had been alive to read the 2007 Brill Companion to Anabaptism and Spiritualism volume mentioned above, he would likely have pointed out one lacuna in English language research today. Of the three strains of the radical Reformation that Williams had distinguished, the "Evangelical Rationalists" are all but absent in the Brill Companion. Such groups as fall under that third 
category, namely, Unitarians, Socinians, and other reforming individuals and groups who fit neither of the two categories treated in the Brill Companion-especially those arising from radicalism in Italy, Spain, and eastern Europe-are those whom he had sought tirelessly to connect in his schema with the other major traditions of the radical Reformation.

\section{Italian Anabaptism}

One clear leader among the young generation of radical Reformation scholars in Europe is Martin Rothkegel, a Baptist historian in Berlin. He has collected and is editing a multi-volume series of source texts that cover the regions of Moravia, Silesia, Bohemia, and beyond, which will be published in the series Quellen zur Geschichte der Täufer. In the course of this project he explored connections between Hutterite colonies and contacts in Italy and the Venetian Republic. ${ }^{95}$ After collecting roughly ten thousand images of Inquisition files, primarily in Venice, Rothkegel built an editorial board consisting of himself plus Italian scholars - including Italians Giovanna Paolin (Trieste) and Federica Ambrosini (Venice), and the German Lothar Vogel (Rome). Rothkegel invited me to be executive editor of the collection. In March 2014, the team met in Venice-Mestre to establish the parameters of the project, and we are now seeking funding to move forward with the project. In terms of filling the Brill Companion's gap of the so-called "Evangelical Rationalists", this project will make these rare original language texts (Latin, Italian, Venetian, and German), with summaries and editorial remarks in English, available to a broad audience.

\section{Conclusion}

Most noteworthy over the course of the last half-century of Anabaptist studies in Canada are the collegiality and productive engagement between scholars of various confessions, the ongoing efforts to broaden the geographic scope of early Anabaptist movements, and the general acceptance of the positive role of "profane" historians in what some consider the domain of ecclesiastical history. The admission that Spiritualism and even Pietism have, generally speaking, a complementary role to play in understanding the Anabaptist traditions has 
also allowed for more nuanced and less theologically restrictive approaches to radical Protestantism in Europe. The proportionately high involvement of Canadian scholars, Mennonites in particular, in the Marpeck renaissance demonstrates that for Canadians, ironically or not, moderating figures are central to understanding Anabaptism as a radical Reformation tradition. 
